\title{
Currarino Syndrome and HPE Microform Associated with a 2.7-Mb Deletion in 7q36.3 Excluding SHH Gene
}

\author{
C. Coutton ${ }^{a, d}$ B. Poreau ${ }^{b}$ F. Devillard ${ }^{a} \quad$ C. Durand ${ }^{c} \quad$ S. Odent ${ }^{e} \quad$ C. Rozel $^{f}$ \\ G. Vieville $^{a}$ F. Amblard ${ }^{a}$ P.-S. Jouk ${ }^{b} \quad$ V. Satre Sa, $^{a}$ \\ a Laboratoire de Génétique Chromosomique, b Service de Génétique Clinique, Département de Génétique et \\ Procréation, 'Service de Radiopédiatrie, Hôpital Couple Enfant, CHU Grenoble, and d AGIM CNRS FRE3405, Equipe \\ 'Andrologie, Génétique et Cancer', Université Joseph Fourier, Grenoble, and 'Service de Génétique Clinique, and \\ fService de Radiologie et Imagerie Médicale, Hôpital Sud, Rennes, France
}

\section{Key Words}

Currarino syndrome $\cdot$ Holoprosencephaly $\cdot$ Long-range enhancers · Microdeletion 7q36 · Sonic hedgehog

\begin{abstract}
Holoprosencephaly (HPE) is the most common forebrain defect in humans. It results from incomplete midline cleavage of the prosencephalon and can be caused by environmental and genetic factors. HPE is usually described as a continuum of brain malformations from the most severe alobar HPE to the middle interhemispheric fusion variant or syntelencephaly. A microform of HPE is limited to craniofacial features such as congenital nasal pyriform aperture stenosis and single central maxillary incisor, without brain malformation. Among the heterogeneous causes of HPE, point mutations and deletions in the $\mathrm{SHH}$ gene at $7 \mathrm{q} 36$ have been identified as well as extremely rare chromosomal rearrangements in the longrange enhancers of this gene. Here, we report a boy with an HPE microform associated with a Currarino syndrome. Array CGH detected a de novo 2.7-Mb deletion in the 7q36.3 region including the MNX1 gene, usually responsible for the Currarino triad but excluding $\mathrm{SH}$, which is just outside the deletion. This new case provides further evidence of the importance of the SHH long-range enhancers in the HPE spectrum.
\end{abstract}

(c) 2013 S. Karger AG, Basel

\section{KARGER}

(c) 2013 S. Karger AG, Basel

$1661-8769 / 13 / 0051-0025 \$ 38.00 / 0$

E-Mail karger@karger.com

www.karger.com/msy
Holoprosencephaly (HPE) is the most common malformation of the human forebrain resulting from incomplete cleavage of the prosencephalon associated with an abnormal development of midline neural structures early in gestation. It is estimated to occur in $1 / 16,000$ live births and $1 / 250$ conceptuses [Dubourg et al., 2007].

Four neuroanatomical classes of HPE are described in decreasing order of severity: alobar, semi-lobar, lobar, and middle interhemispheric variants or syntelencephaly. In $80 \%$ of affected individuals, a large spectrum of different craniofacial anomalies is also present [Solomon et al., 2011]. In the clinical subtypes of HPE, microforms are characterized by facial midline defects (e.g. solitary maxillary central incisor, hypotelorism, flat nasal bridge, midface hypoplasia, and congenital nasal pyriform aperture stenosis) without neurologic findings [Mercier et al., 2011]. The etiology of HPE is heterogeneous and may result from environmental, metabolic factors, prenatal exposures to drugs or infections. Numerical and structural chromosomal abnormalities as well as gene mutations are also responsible for isolated or syndromic HPE. To date, more than 14 causative genes have been identified [Solomon et al., 2011]. Among them, point mutations and gene deletions of the $S H H$ (sonic hedgehog) gene (MIM 600725) at 7q36, responsible for SHH haploinsufficiency, were first

Charles Coutton

Service de Génétique Chromosomique, Hôpital Couple-Enfant, CHU de Grenoble Avenue Maquis du Gresivaudan

FR-38043 Grenoble (France)

E-Mail ccoutton@chu-grenoble.fr 
identified [Belloni and Roessler, 1996]. SHH is the most frequently mutated gene in HPE accounting for approximately $12 \%$ of cases [Roessler et al., 2009]. Despite of no clear phenotype-genotype correlation, the mutations of this gene are more related to milder forms of HPE such as microforms than those in other common HPE-related genes [Mercier et al., 2011; Solomon et al., 2012].

The Currarino triad associates partial sacral agenesis with presacral mass and anorectal malformations. Mutations in the gene MNX1 (HLXB9) (MIM 142994), located in $7 q 36.3$, were identified in nearly all patients with a familial form of Currarino syndrome and in $30 \%$ of those with a sporadic form [Lynch et al., 2000].

Large subtelomeric deletions in 7q36.3 have also been associated with patients presenting HPE and Currarino syndrome due to the loss of the MNX1 and SHH genes. $\mathrm{SHH}$ is located $1.2 \mathrm{Mb}$ proximal to MNX1 [Lynch et al., 1995; Horn et al., 2004]. Chromosomal rearrangements like translocations or inversions with breakpoints mapped in the $5^{\prime}$ upstream region of the $S H H$ locus have been described in very few patients with HPE [Belloni et al., 1996; Roessler et al., 1997; Lettice et al., 2011]. The 5' upstream $1-\mathrm{Mb}$ genomic region, starting from the $\mathrm{SHH}$ coding region to LMBR1 (the limb development membrane protein 1) gene, contains a lot of evolutionarily highly-conserved long-range $\mathrm{SHH}$ enhancers. These enhancers promote SHH expression in key signaling pathways which are fundamental for forebrain, craniofacial, epithelial, and limb development. The specific forebrain enhancers (SBE1-4) are localized within $\mathrm{SHH}$ introns and 350-500 kb 5'upstream of the $S H H$ gene (fig. 1) [Jeong et al., 2006].

We report a case of a boy with a microform of HPE and a Currarino syndrome associated with a $2.7-\mathrm{Mb}$ deletion in the $7 \mathrm{q} 36.3$ region. Interestingly, this deletion includes the MNX1, but not the $S H H$ gene.

\section{Case Report}

The propositus was born at 37 weeks of gestation by caesarean section from nonconsanguineous healthy parents with no family history of congenital anomalies or developmental delay. No ultrasound abnormality was found during pregnancy. At 31 gestational weeks, the mother was treated by corticosteroid therapy because of a threatened preterm labor.

At birth, the patient was eutrophic [weight: 2,720 g (10-50th percentile), cranial perimeter: $32 \mathrm{~cm}$ (10th percentile)]. He presented hypotonia and an acute respiratory distress syndrome. In addition, he had abdominal distension, persistent vomiting and failure to pass meconium in the first $24 \mathrm{~h}$. The exploration of this subocclusive syndrome by ultrasound and MRI scan revealed no digestive abnormalities but a partial sacral agenesis associated with a presacral lipoma, a low-lying spinal cord and an obstructive megaureter, but no anorectal malformations. A syringomyelic filiform cavity was detected between $\mathrm{T} 8$ and T10 vertebras. These abnormalities suggested an atypical Currarino syndrome.

A craniofacial CT scan revealed a congenital nasal pyriform aperture stenosis of about 5 millimeters (fig. $2 a$ ) as well as a single median maxillary incisor (fig. 2b). The pyriform stenosis was surgically treated. A magnetic resonance imaging scan showed no detectable structural brain anomalies.

Hypotelorism and iris, optic nerve and chorioretinal colobomas were also noted. All these clinical and radiological arguments were consistent with a HPE microform. No limb malformations were observed.

A standard G- and R-banding karyotype performed on lymphocyte cultures of peripheral blood was normal, 46,XY. A subtelomeric chromosome study using multiplex ligation-dependant probe amplification (MRC Holland, Amsterdam, The Netherlands) was normal.

\section{Materials and Methods}

Array CGH was performed using an 180,000-oligonucleotide microarray (Human Genome CGH Microarray Kit 180K, Agilent Technologies, Santa Clara, Calif., USA) according to the manufacturer's instructions. The average spacing of the probes was $13 \mathrm{~kb}$. DNA from the patient was compared with DNA from 2 other patients with different diseases, according to the loop model [Menten et al., 2006]. Genomic Workbench software standard edition 6.5 (Agilent) was used to interpret the results with the following parameters: aberration detection algorithm 2, threshold 6.0, fuzzy zero, centralization, and moving average window $1 \mathrm{Mb}$. A copy number variation was noted if at least 3 contiguous oligonucleotides showed an abnormal $\log _{2}$ ratio $(>+0.58$ or $<-1$ according to the Alexa 5 deviation) with a mirror image. The Database of Genomic Variants (http://projects.tcag.ca/variation/) was used to compare findings to previously reported studies. Coordinates of copy number variations are based on the GRCh37/hg19 assembly.

A FISH analysis was performed on interphase nuclei and metaphase chromosomes, using RP5-982E9 (Chr7:156,351,383156,509,576; hg19) localized in the $2.7-\mathrm{Mb}$ deletion.

\section{Results}

Array CGH analysis showed a deletion in chromosome band 7q36.3. The 2.7-Mb deletion extends from base $155,686,857$ (first deleted oligonucleotide) to $158,384,574$ (last deleted oligonucleotide) (NCBI, hg19) from the $7 \mathrm{p}$ telomere (fig. 3). No other abnormalities larger than 3 probes were observed, excluding well-known benign copy number variations (Database of Genomic Variants).

The 2.7-Mb deletion was confirmed by FISH analysis on interphase nuclei and metaphase chromosomes. FISH analyses of the parents' peripheral lymphocytes were normal, suggesting that the abnormality detected in the patient was de novo and likely causative of the patient's phenotype. 


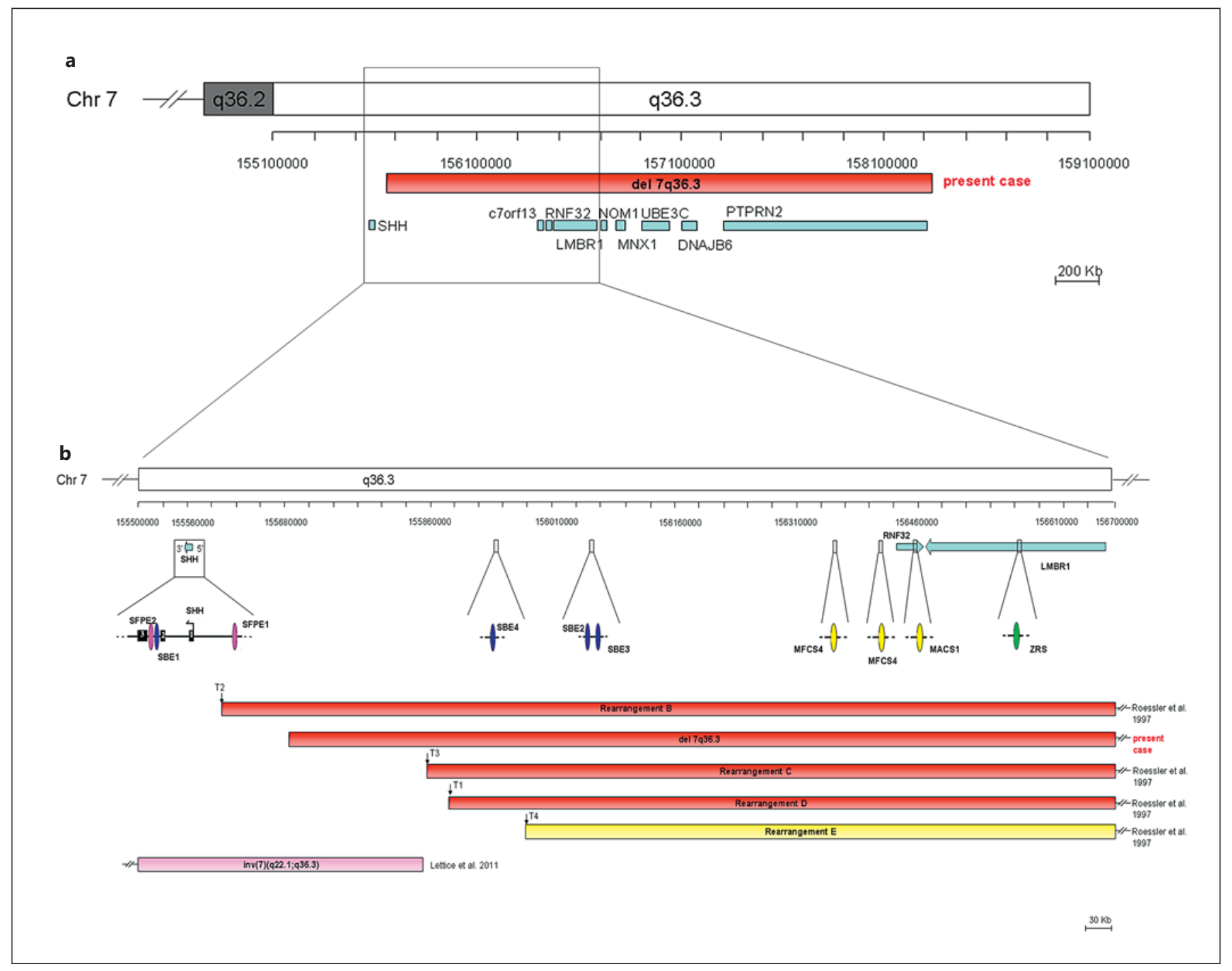

Fig. 1. Mapping of the deletion in 7q36.3. a Schematic representation of the 7q36.3 deletion described in our patient. Known protein-coding genes included in the deletion are reported in blue. The boxed section corresponds to the proximal breakpoint of the presented deletion. $\mathbf{b}$ Genomic view of the $7 \mathrm{q} 36.3$ region close to the SHH gene. Translocation breakpoints of T1-T4 (black arrows) in 7q36.3 and respective deletions in derivative chromosome 7 (rearrangements B, C, D, and E) described by Roessler et al. [1997] are reported (solid bars). The breakpoints are approximated in

\section{Discussion}

In the $2.7-\mathrm{Mb}$ region, 13 genes (7 known protein-coding genes, 2 miRNA genes and 4 other noncoding RNA genes) are listed in NCBI (GRCh37/hg19). Among them, LMBR1 (MIM 605522), MNX1 and DNAJB6 (MIM 611332) are disease-causing genes (fig. 1a).

HPE Microform and 7q36.3 Deletion

Excluding $\mathrm{SHH}$ Gene these cases. Genomic imbalances associated with HPE phenotype are colored in red and with no HPE features in yellow. Chromosomal inversion (7)(q22.1;q36.3) reported by Lettice et al. [2011] is also represented (solid pink bar). The known cis-regulatory enhancers of $\mathrm{SHH}$ at 7q36.3 are indicated with colored circles: $\mathrm{SHH}$ floor plate enhancers $(S F P E 1+2)$ in purple, brain enhancers (SBE1-4) in blue, epithelial enhancers (MACS1, MRCS1 and MFCS4) in yellow, and the limb-specific enhancer (ZRS) is shown in green.
$M N X 1$, previously known as $H L X B 9$, encodes a transcription factor with a homeobox domain. MNX1 loss-offunction mutations including point mutations, chromosomal rearrangements or whole-gene deletions are associated with Currarino syndrome (OMIM 176450) [Crétolle et al., 2008; Markljung et al., 2012; Holm et al., 2013]. This autosomal dominant disorder was initially 
Fig. 2. Craniofacial CT scans of the patient. a Axial CT scan showing congenital pyriform aperture stenosis. b Axial CT scan showing solitary median maxillary incisor (arrow).
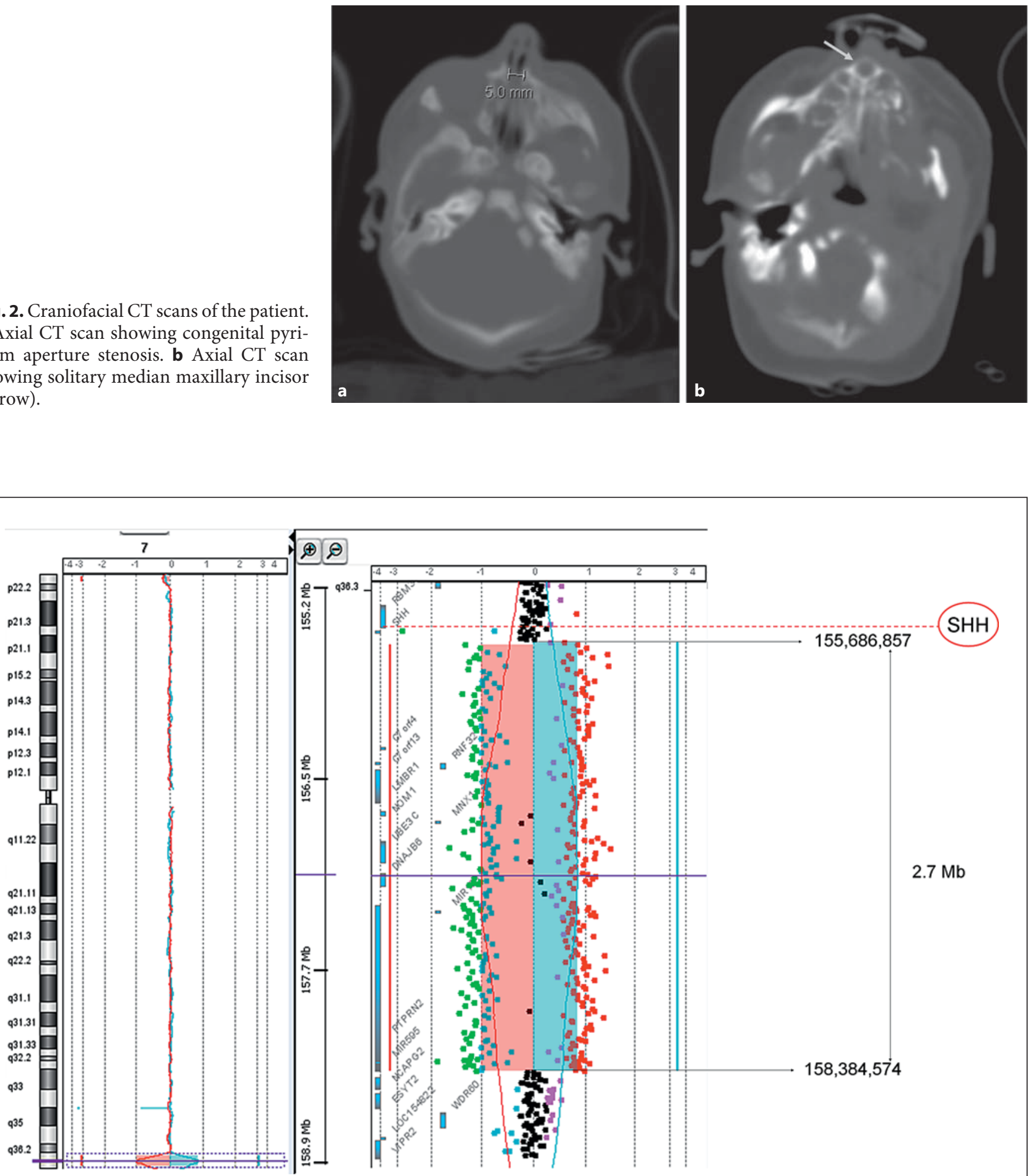

Fig. 3. Array CGH analysis of the microdeletion in chromosome 7 of our patient. Array CGH profile of chromosome 7 shows a 2.7-Mb heterozygous deletion in 7q36.3. Genomic position of the first deleted $(7: 155,686,857)$ and the last deleted oligonucleotides $(7: 158,384,574)$ are indicated with black arrows. The SHH gene (red circle) is located upstream of the first deleted oligonucleotides. 
described as a triad of anorectal, sacral and presacral anomalies [Currarino et al., 1981]. Currarino syndrome exhibits variable expressivity and incomplete penetrance [Horn et al., 2004]. A broad clinical spectrum has been reported, and anorectal malformations appear inconstant in Currarino syndrome [Crétolle et al., 2008]. Our patient presents a partial sacral agenesis associated with a presacral mass (lipoma), but no anorectal malformations. These signs can be related to MNX1 haploinsufficiency.

LMBR1 (MIM 605522) is required for limb formation. A long-range cis-regulatory element located within intron 5 of the $L M B R 1$ gene governs normal SHH expression level, in the posterior zone of polarizing activity region. An evolutionary-conserved region, called the zone of polarizing activity regulatory sequence (ZRS; MIM 605522), is located about $1 \mathrm{Mb}$ upstream from $\mathrm{SHH}$ and has enhancer activity that directs $\mathrm{SHH}$ expression in the developing posterior limb bud [Lettice et al., 2003]. ZRS mutations or duplications have been identified causing a wide range of limb malformations [VanderMeer and Ahituv, 2011]. Our patient has no limb abnormalities. In the Database of Genomic Variants, some copy number variations which result in a heterozygous deletion of LMBR1 are reported [Wong et al., 2007; Pinto et al., 2011]. In the Database of Chromosomal Imbalance and Phenotype in Humans Using Ensembl Resources (http://decipher.sanger.ac.uk/), one deletion inherited from a healthy parent (ID 263779) is also reported suggesting that heterozygous deletions of $L M B R 1$ are unlikely to be involved in a limb phenotype.

Our patient presents a mild holoprosencephaly spectrum phenotype. HPE reported with a $7 \mathrm{q} 36.3$ deletion usually includes $\mathrm{SHH}$ and is linked to its haploinsufficiency [Horn et al., 2004]. Our patient's deletion does not include $\mathrm{SHH}$, which is $100 \mathrm{~kb}$ away from the proximal breakpoint (fig. 1a). There are very few clinical reports of HPE with cytogenetic rearrangements in 7q36.3 excluding the SHH gene. Roessler et al. [1997] reported the clinical features of patients with 4 different reciprocal translocations involving chromosome 7 (T1-T4) in which the breakpoints are in the $7 \mathrm{q} 36.3$ region. In these translocations, the centromeric breakpoints also map near $\mathrm{SHH}$, but do not interrupt it. Most of these patients exhibit a mild HPE spectrum or a microform (table 1). All T4 patients with balanced translocations or the $\operatorname{der}(7)$ have no HPE phenotype (table 1). Although a variable expressivity cannot be excluded, the analysis of all the patients and our present case suggests that the minimal critical region might be situated in a 90-kb segment between T1 and T4 breakpoints [Roessler et al., 1997]. Interestingly, an $\mathrm{SHH}$ forebrain enhancer, SBE4, is located in the middle of this segment (fig. 1b).

Recently, Lettice et al. [2011] described a de novo 7q inversion $[\operatorname{inv}(7)(q 22.1 ; \mathrm{q} 36.3)]$ in a child with features of a holoprosencephaly spectrum (hypotelorism, microcephaly and solitary maxillary central incisor) and severe upper and lower limb syndactyly (table 1). MRI scan showed no detectable structural brain anomalies. The author suggested that limb anomalies are due to an enhancer adoption caused by the inversion, relocating the $\mathrm{SHH}$ gene close to a novel limb bud enhancer located in $7 \mathrm{q} 22.1$ [Lettice et al., 2011].

SHH mutations are most often associated with a microform or mild HPE, in contrast to mutations in other common HPE-related genes [Mercier et al., 2011; Solomon et al., 2012]. In the same way, it seems that a HPE phenotype associated with cytogenetic rearrangements occurring in the upstream portion of $\mathrm{SHH}$ gene is more often mild with predominantly HPE microforms (table 1). However, a broad clinical spectrum is observed, and no precise correlation between the phenotype and the genotype can be currently established. The variable HPE phenotype could be explained in different ways such as the extent of the deletion, an effect of an additional chromosomal imbalance, a possible position effect of the juxtaposed chromosomal regions which could modulate the expression of $S H H$ [Lettice et al., 2011], mutations or deletion in another gene [Mercier et al., 2011], or additional environmental effects. Another explanation could be a possible imprinting effect at the $\mathrm{SHH}$ locus with disruption of an imprinting domain leading to an abnormal phenotype in some individuals, but not in some others [Lukusa et al., 2005].

Overall, in the reported cases above and in our present case, HPE spectrum is most likely due to the $7 \mathrm{q} 36.3$ breakpoints dislocating the $\mathrm{SHH}$ gene from its upstream forebrain enhancers (fig. 1b) [Jeong et al., 2006]. The SBE4 enhancer disruption might play a preponderant role in the HPE spectrum. However, Jeong et al. [2008] also reported a patient with semilobar HPE caused by a rare nucleotide variant located $460 \mathrm{~kb}$ upstream of $\mathrm{SHH}$ resulting in the loss of SBE2 activity. The parents' genotype revealed that the father was an unaffected carrier suggesting that in this case, additional multigenic or multifactorial effects are necessary to explain the HPE phenotype in the proband.

Other SHH enhancers are included in the deletion of our patient and in particular the long-range epithelial SHH enhancers (MRCS1, MFCS4 and MACS1) (fig. 1b) [Sagai et al., 2009]. The loss of the specific dental placode 
Table 1. Holoprosencephalic findings in our patient with de novo $7 \mathrm{q} 36$ deletion and patients with chromosomal rearrangements involving 7q36 (reported in Roessler et al. [1997] and Lettice et al. [2011]) and not including SHH gene

\begin{tabular}{|c|c|c|c|c|c|c|c|c|c|}
\hline \multirow{2}{*}{$\begin{array}{l}\text { Patients } \\
\text { Chromosomal } \\
\text { rearrangements }\end{array}$} & \multicolumn{2}{|c|}{$\begin{array}{l}\text { T1 } \\
\text { [Roessler et al., 1997] }\end{array}$} & $\begin{array}{l}\text { T2 } \\
\text { [Roessler et al., 1997] }\end{array}$ & \multicolumn{2}{|c|}{$\begin{array}{l}\text { T3 } \\
\text { [Roessler et al., 1997] }\end{array}$} & \multicolumn{2}{|c|}{$\begin{array}{l}\text { T4 } \\
\text { [Roessler et al., 1997] }\end{array}$} & \multirow{2}{*}{$\begin{array}{l}\begin{array}{l}\text { Lettice et al. } \\
{[2011]}\end{array} \\
\text { inv(7) } \\
(\mathrm{q} 22.1 ; \mathrm{q} 36.3)\end{array}$} & \multirow{2}{*}{$\begin{array}{l}\text { Present case } \\
\text { arr } \\
7 \mathrm{q} 36.3(155,686,857- \\
158,384,574) \times 1\end{array}$} \\
\hline & $\mathrm{t}(7 ; 9)(\mathrm{q} 36 ; \mathrm{q}$ & 34) & $\mathrm{t}(6 ; 7)(\mathrm{p} 21 ; \mathrm{q} 36)$ & $\mathrm{t}(2 ; 7)(\mathrm{q} 31$ & ;q36) & $\mathrm{t}(7 ; 17)(\mathrm{q} 3$ & 6;p12) & & \\
\hline Status & balanced & $\begin{array}{l}\text { unbalanced } \\
\operatorname{der}(7)\end{array}$ & balanced & balanced & $\begin{array}{l}\text { unbalanced } \\
\text { der(7) }\end{array}$ & balanced & $\begin{array}{l}\text { unbalanced } \\
\text { der(7) }\end{array}$ & balanced & unbalanced \\
\hline \multicolumn{10}{|l|}{ Brain finding of HPE } \\
\hline HPE subtype & microform & unknown & unknown & no HPE & microform & no HPE & no HPE & microform & microform \\
\hline $\begin{array}{l}\text { Other brain } \\
\text { abnormalities }\end{array}$ & - & - & mild volume loss & l & $\begin{array}{l}\text { arhinen- } \\
\text { cephaly }\end{array}$ & l & l & - & $\begin{array}{l}\text { hypoplasia of the } \\
\text { pyriform aperture }\end{array}$ \\
\hline $\begin{array}{l}\text { Single median } \\
\text { incisor }\end{array}$ & - & $+(1 / 2)$ & - & l & - & 1 & l & + & + \\
\hline $\begin{array}{l}\text { Other teeth } \\
\text { anomalies }\end{array}$ & $+(2 / 3)$ & $+(1 / 2)$ & + & l & - & l & l & - & - \\
\hline Cleft palate & $+(1 / 3)$ & $+(1 / 2)$ & + & l & - & l & l & - & - \\
\hline Cleft lip & - & - & + & l & - & 1 & l & - & + \\
\hline $\begin{array}{l}\text { Flat nose/nasal } \\
\text { bridge }\end{array}$ & $+(3 / 3)$ & $+(2 / 2)$ & + & l & - & l & I & - & - \\
\hline Ear anomalies & $+(3 / 3)$ & $+(2 / 2)$ & + & 1 & + & 1 & l & - & + \\
\hline
\end{tabular}

enhancer MRCS1 may be associated with solitary maxillary central incisor [Lettice et al., 2011]. Involvement of MFCS4 and MACS1 is still uncertain. Furthermore, in mice, the haploinsufficiency of the MFCS4 leads to a normal phenotype [Sagai et al., 2009].

At last, DNAJB6 encodes a highly conserved member of the HSP40/DNAJ cochaperone family. This family regulates the molecular chaperone activity of HSP70 by stimulating ATPase activity [Fan et al., 2003; Vos et al., 2008]. Mutations in DNAJB6 have been recently linked to autosomal dominant limb-girdle muscular dystrophy type $1 \mathrm{E}$ (MIM 603511) [Harms et al., 2012; Sarparanta et al., 2012]. This disease is characterized by mid-adulthood onset of proximal limb weakness and skeletal muscle pathology [Sandell et al., 2010; Hackman et al., 2011]. At the age of
7 months, as expected, our patient lacks muscular signs. The long-term clinical follow-up will determine if these features are present.

In conclusion, this case provides further evidence of the importance of the $\mathrm{SHH}$ long-range enhancers in the HPE spectrum. This highlights the potential interest of looking for mutations or disruptions of $\mathrm{SHH}$ forebrain enhancers and in particular of SBE4 in HPE microforms without $\mathrm{SHH}$ mutations.

\section{Acknowledgement}

We thank all family members for their interest and cooperation. This study was supported by grants from the French Ministry (DHOS). 


\section{References}

Belloni E, Muenke M, Roessler E, Traverso G, Sie- Jeong Y, Leskow FC, El-Jaick K, Roessler E, gel-Bartelt J, et al: Identification of Sonic hedgehog as a candidate gene responsible for holoprosencephaly. Nat Genet 14:353-356 (1996).

Crétolle C, Pelet A, Sanlaville D, Zérah M, Amiel J, et al: Spectrum of HLXB9 gene mutations in Currarino syndrome and genotype-phenotype correlation. Hum Mutat 29:903-910 (2008).

Currarino G, Coln D, Votteler T: Triad of anorectal, sacral, and presacral anomalies. Am J Roentgenol 137:395-398 (1981).

-Dubourg C, Bendavid C, Pasquier L, Henry C, Odent S, David V: Holoprosencephaly. Orphanet J Rare Dis 2:8 (2007).

-Fan CY, Lee S, Cyr DM: Mechanisms for regulation of Hsp70 function by Hsp40. Cell Stress Chaperones 8:309-316 (2003).

-Hackman P, Sandell S, Sarparanta J, Luque H, Huovinen S, et al: Four new Finnish families with LGMD1D; refinement of the clinical phenotype and the linked 7q36 locus. Neuromuscul Disord 21:338-344 (2011).

- Harms MB, Sommerville RB, Allred P, Bell S, Ma $\mathrm{D}$, et al: Exome sequencing reveals DNAJB6 mutations in dominantly-inherited myopathy. Ann Neurol 71:407-416 (2012).

-Holm I, Monclair T, Lundar T, Stadheim B, Prescott TE, Eiklid KL: A 5.8 kb deletion removing the entire $M N X 1$ gene in a Norwegian family with Currarino syndrome. Gene 518: 457-460 (2013).

-Horn D, Tönnies H, Neitzel H, Wahl D, Hinkel GK, et al: Minimal clinical expression of the holoprosencephaly spectrum and of Currarino syndrome due to different cytogenetic rearrangements deleting the sonic hedgehog gene and the HLXB9 gene at $7 \mathrm{q} 36.3$. Am J Med Genet A 128A:85-92 (2004).

-Jeong Y, El-Jaick K, Roessler E, Muenke M, Epstein DJ: A functional screen for sonic hedgehog regulatory elements across a $1 \mathrm{Mb}$ interval identifies long-range ventral forebrain enhancers. Development 133:761-772 (2006). Muenke M, et al: Regulation of a remote Sonic hedgehog forebrain enhancer by the Six3 homeoprotein. Nat Genet 40:1348-1353 (2008).

Lettice LA, Heaney SJ, Purdie LA, Li L, de Beer P, et al: A long-range Shh enhancer regulates expression in the developing limb and fin and is associated with preaxial polydactyly. Hum

Lettice LA, Daniels S, Sweeney E, Venkataraman S, Devenney PS, et al: Enhancer-adoption as a mechanism of human developmental disease. Hum Mutat 32:1492-1499 (2011).

Lukusa T, Vermeesch JR, Fryns JP: De novo deletion $7 q 36$ resulting from a distal 7q/8q translocation: phenotypic expression and comparison to the literature. Genet Couns 16:1-15 (2005). $S$, et al: A gene for autosomal dominant sacral agenesis maps to the holoprosencephaly region at 7q36. Nat Genet 11:93-95 (1995).

Lynch SA, Wang Y, Strachan T, Burn J, Lindsay S: Autosomal dominant sacral agenesis: Currarino syndrome. J Med Genet 37:561-566 (2000).

Markljung E, Adamovic T, Cao J, Naji H, Kaiser $\mathrm{S}$, et al: Novel mutations in the MNX1 gene in two families with Currarino syndrome and variable phenotype. Gene 507:50-53 (2012).

-Menten B, Maas N, Thienpont B, Buysse K, Vandesompele J, et al: Emerging patterns of cryptic chromosomal imbalance in patients with idiopathic mental retardation and multiple congenital anomalies: a new series of 140 patients and review of published reports. Med Genet 43:625-633 (2006).

- Mercier S, Dubourg C, Garcelon N, CampilloGimenez B, Gicquel I, et al: New findings for phenotype-genotype correlations in a large European series of holoprosencephaly cases. J Med Genet 48:752-760 (2011).

$\checkmark$ Pinto D, Darvishi K, Shi X, Rajan D, Rigler D, et al: Comprehensive assessment of array-based platforms and calling algorithms for detection of copy number variants. Nat Biotechnol 29: 512-520 (2011).

- Roessler E, Ward DE, Gaudenz K, Belloni E, Scherer SW, et al: Cytogenetic rearrangements involving the loss of the Sonic Hedgehog gene at 7q36 cause holoprosencephaly. Hum Genet 100:172-181 (1997). Mol Genet 12:1725-1735 (2003).

Lynch SA, Bond PM, Copp AJ, Kirwan WO, Nour
Roessler E, El-Jaick KB, Dubourg C, Vélez JI, Solomon BD, et al: The mutational spectrum of holoprosencephaly-associated changes within the $\mathrm{SHH}$ gene in humans predicts loss-offunction through either key structural alterations of the ligand or its altered synthesis. Hum Mutat 30:E921-E935 (2009).

Sagai T, Amano T, Tamura M, Mizushina Y, Sumiyama K, Shiroishi T: A cluster of three long-range enhancers directs regional Shh expression in the epithelial linings. Development 136:1665-1674 (2009).

-Sandell S, Huovinen S, Sarparanta J, Luque H, Raheem O, et al: The enigma of 7q36 linked autosomal dominant limb girdle muscular dystrophy. J Neurol Neurosurg Psychiatry 81: 834-839 (2010).

Sarparanta J, Jonson PH, Golzio C, Sandell S, Luque $\mathrm{H}$, et al: Mutations affecting the cytoplasmic functions of the co-chaperone DNAJB6 cause limb-girdle muscular dystrophy. Nat Genet 44:450-455 (2012).

Solomon BD, Gropman A, Muenke M: Holoprosencephaly overview, in Pagon RA, Adam MP, Bird TD, Dolan CR, Fong CT, Stephens K (eds): GeneReviews (University of Washington, Seattle 2011). http://www.ncbi.nlm.nih. gov/books/NBK1530/.

Solomon BD, Bear KA, Wyllie A, Keaton AA, Dubourg $\mathrm{C}$, et al : Genotypic and phenotypic analysis of 396 individuals with mutations in Sonic Hedgehog. J Med Genet 49:473-479 (2012).

VanderMeer JE, Ahituv N: cis-regulatory mutations are a genetic cause of human limb malformations. Dev Dyn 240:920-930 (2011).

$>$ Vos MJ, Hageman J, Carra S, Kampinga HH: Structural and functional diversities between members of the human HSPB, HSPH, HSPA, and DNAJ chaperone families. Biochemistry 47:7001-7011 (2008).

Wong KK, deLeeuw RJ, Dosanjh NS, Kimm LR, Cheng Z, et al: A comprehensive analysis of common copy-number variations in the human genome. Am J Hum Genet 80:91-104 (2007).
HPE Microform and 7q36.3 Deletion Excluding $\mathrm{SHH}$ Gene
Mol Syndromol 2014;5:25-31 DOI: $10.1159 / 000355391$ 